\title{
Satisfaction Levels of Sports Event Participants
}

\author{
${\text { Huseyin } \text { Gokce }^{1} \& \text { Elif Bozyigit }}^{1}$ \\ ${ }^{1}$ Faculty of Sport Sciences, Pamukkale University, Denizli, Turkey \\ Correspondence: Huseyin Gokce, Faculty of Sport Sciences Recreation Department, Pamukkale University, \\ Denizli, Turkey. E-mail: hgokce@pau.edu.tr
}

Received: November 5, 2019

Accepted: December 19, 2019 Online Published: January 6, 2020

doi:10.5539/jel.v9n1p136

URL: https://doi.org/10.5539/jel.v9n1p136

\begin{abstract}
The aim of the study is to compare the satisfaction levels of the participants, participating in the sports festival according to some variables. The survey was conducted to 1,274 people randomly selected among approximately 55,000 participants who participated in the sports festival organized by a municipality in Denizli-Turkey. As a data collection tools "Personal Information Form" prepared by the researchers and the "Festival Satisfaction Survey" which was developed by Yoon et al. (2010) and adopted into Turkish by Tayfun and Arslan (2013). The data collection forms applied to the participants during the festival and the data were checked in terms of normal distributions in the statistical analysis program and analyzed by using independent samples $\mathrm{T}$ test and ANOVA analysis methods. As a result of the analysis, male participants perceived a significant level of satisfaction in the sub-dimensions of program, value, satisfaction and loyalty from the questionnaire. A significant difference was found in the sub-dimensions of knowledge, value, satisfaction, and loyalty in the examination conducted by occupational groups. It is seen that this difference is caused by the public employees' higher satisfaction level. Another hypothesis of the study was to compare the satisfaction of participants according to their educational status. Significant differences were found in the sub-dimensions of knowledge, value, satisfaction, loyalty. It is seen that reason for the statistically meaningful difference, primary school graduates feel lower satisfaction from the festival in terms of education level. As a result, it is thought that participants of the sport festivals feel different satisfaction in terms of their gender, education status and working situation and while planning that kind of events these characteristics must be taken into consideration.
\end{abstract}

Keywords: sport, event, festival, participant, satisfaction

\section{Introduction}

Events, which are important aspects of our social life, are in a complex structure due to its nature which requires high organization skills (Johnston \& Zawawi, 2004). The term of event can be referred to various situations including parades, competitions, meetings, congress, festivals, parties, and sports events. In the light of literature, definitions are as follows: "An incomparable fulfillment of special needs with ceremonies and parades" (Goldblatt, 2001), "all of the activities conducted in a certain place and time" (Eckerstein, 2003), "an experience designed for creating an effect on the participants" (Silver et al., 2004).

While events that are used to define activities with different purposes may be related to art, tourism, social and sports events, they can also be organized as large events that are organized more professional and formal and conducted by large-scale organizations (Argan, 2007). Events (special incidents) are observed as an alternative method and a differentiating element for nation branding. Special events such as festivals, cultural/artistic/sportive organizations are observed as the most important tools of modern tourism in creating an image (Johnston \& Zawawi, 2004).

McDonnell et al. (1999) classified the festival and special-purpose events in three categories. These are events that draw significant amount of visitors and participants, provide economic and social contributions and draw the attention of media and these events can be stated as; a) "Mega Events" that significantly affect the national economy such as Olympics and World Fairs, b) "Hallmark Events" which reflect the spirit and identity of a city or a region and creates the brand value of the region such as Rio De Janeiro Carnival in Brazil or October Fest in Munich, Germany, and c) "Big Regional Events and Organizations" such as International Aspendos Festival, Runatolia, and Run to Sky that are organized in Antalya and International Intercontinental Eurasia Marathon in İstanbul. Furthermore, it can be observed that the events are also classified in accordance with their scale 
(magnitude and extent), related fields (theme), planning condition and special event type. According to the scale; Magnitude and extent: Geographical scope, number of participants, media attention, infrastructure, cost, contributions. Events are classified into four as mega, hallmark, big and local events according to their scale (Argan, 2007). According to the related field (theme): Fair, festival, opening, celebration, sportive, cultural, theme parks, awards ceremony, family activities, etc. According to the plan made by Tassiopoulos (2005), the events are classified by paying attention to their authenticity, exclusiveness and magnitude criteria. The events are classified into two as planned (ordinary and special) and unplanned. Special events are events that rarely happen, can be organized out of the program and usually have a theme. They can be classified as cultural, individual and business events that are organized in free-time.

Sports events are activities that are organized within a program for accomplishing the management of seminar, meeting, course, panel, camp and all sorts of sports events that are organized to serve the purpose of sports competitions. There are certain differences that separate sports organizations that do not include only sports competitions from other organizations (Demirci, 1986). It can be observed that the magnitude of sports organizations never changes the general definition of the organization. Sports events are special events that include complexity, competition, multi-purposes, objects, and products which have strong organizational culture and potential marketing history. Since sports events have the potential to affect society and culture, nature and environment, politics, tourism and economy, lots of countries want to organize sports events (Vu \& Wang, 2016).

These organizations vary in a way that they cannot be classified under one title since, in the sports events, participation, extent, intensity, aesthetics, and excitement are exhibited at the same time. Various classifications can be observed for these events.

Sports events can be classified according to their time and place; events that are organized annually in the same place, events that are organized in different times and places and simultaneous sports events, according to their importance; local and regional, national and international, continental and intercontinental and global sports events, according to their features; free-time, touristic, professional and sports events that support other events (Shone \& Parry, 2004).

Individuals, who do not have much knowledge and interest and are from various social classes and groups, also participate in sports events. Participants in sports events are classified into three as active and passive participants and members of press (Argan et al., 2013). While active participants include the athletes and sports teams that perform sports participation and the delegations of national or international sports clubs or the Olympic Committee, passive participants are the spectators. Today, there is a significant number of participants that watch the sportive events live. Media members, on the other hand, try to be different, distinguishable from others (i.e., rivals) and remarkable in order to be successful and efficient (Rızaoğlu, 2003) and they are the most important tools for branding in terms of countries or cities with festivals, cultural/artistic/sportive events (Smith \& Jenner, 1998).

Event satisfaction is crucially important for events like any other fields in the service sector. According to Anderson et al. (2004), event satisfaction is conceptualized as an element that would affect the experiences of individuals they participated in to the participation of other events. According to the results of the study, satisfied customers are more dependent on the organization and loyal to the brand and accept the price increases more easily. Oliver (1980) emphasized that the balance between the satisfaction and dissatisfaction of customers depends on the expectancies of customers and the service they receive with "Expectancy Disconfirmation Model". In other words, the balance or imbalance between the expectancies of customers and their experience is the determinant of customer satisfaction level. Service quality is one of the main factors that affect the long-term profitability of an organization (Parasuraman et al., 1988). Elements such as perceived high service quality, consumer satisfaction, loyalty, etc. are significant potentials in increasing the income of an organization (Zeithaml et al., 1996). An experience of good quality that meets the expectancies of consumers can motivate the participation and consumption of a probable event in the future.

There are different theories regarding customer satisfaction. These theories can be stated as: "Expectancy Disconfirmation", "Cognitive or Cognitive Dissonance", "Equity", "Assimilation", "Assimilation-Contrast", "Comparison (Comparison Level)" and "Adaptation Level" theories.

There are several elements that are considered to be effective in preferring a service or a product by the customer. These are; perceived quality, brand, risk, tangible and intangible cost, satisfaction, etc. It is required to be different, distinguishable from other information (i.e., from the messages of rivals), remarkable and to use different communication channels in order to be successful and efficient in the publicity of country and product (Rızaoğlu, 2003). 
It can be observed in the literature that studies conducted on sports events are carried out on the examination of behaviors such as service quality and repurchase. To sum up, Theodorakis et al. (2001) examined the relationship between the spectator service quality and customer satisfaction in sports competition by using SPORTSERV model. Theodorakis and Alexandris (2008) used SPORTSERV model in the professional football field in Greece in order to test the validity and reliability of the model. Theodorakis et al. (2013) used the same model in examining the correlator role of general service quality in the relationship between service quality and consumer satisfaction in professional football. Kelley and Turley (2001) evaluated the service quality and customer satisfaction level of supporters during a sports event.

In the literature of festivals, it is considered that the perceived quality of a festival is the premise of satisfaction and loyalty and the conception of perceived value is related to the quality of festival (Huang et al., 2010; Yoon et al., 2010). In conclusion, perceived value, satisfaction, and loyalty or behavioral intentions (recommending to others) directly or indirectly affect the quality of festival (Cole \& Illum, 2006; Lee, Petrick, \& Crompton, 2007; Thrane, 2002).

\section{Method}

\subsection{Study Group}

The number of athletes that participated in a Sports Festival organized in 2018 by a local authority in Denizli province was 2500 and the number of participants/spectators was 55,000. The organized sports events were evaluated in two groups as official competitions (Half Marathon, Taekwondo, Table Tennis, 3X3 Basketball, Field Hockey, Bicycle Race, Public Race, Arrow Shooting Exhibitions, Kick box, Paragliding, and Hang Gliding Exhibition) and booths (trial, competition, spectating). The study group consists of 1374 participants ( Avg $_{\text {age }}=$ $31.8)$ as 604 females $(47.1 \%)$ and 670 males $(52.9 \%)$ that passively participated in these events and were chosen with the convenience sampling method. It was determined that 567 of the participants $(44.3 \%)$ were students, 228 of them (17.9\%) were working in private sector, 356 of them $(27.9 \%)$ were working in public sector and 126 of them were working in other sectors. When their education levels are examined, it was observed that 129 of them $(10.1 \%)$ were primary school graduates, 638 of them $(50.1 \%)$ were secondary school graduates and 507 of them $(39.8 \%)$ were university or higher education graduates. The study was designed with quantitative descriptive research model.

\subsection{Data Collection Tools}

"Personal Information Form" and "Festival Satisfaction Questionnaire (FSQ)" were used as data collection tools. The personal information form included questions such as gender, age, education level, occupation and which event drew your attention the most. Festival Satisfaction Questionnaire was developed by Yood et al. (2010) and adapted to Turkish by Doğrul et al. (2015). The scale which consists of 21 items and 6 sub-dimensions is 7-point Likert type which includes 7 "totally agree" and "totally disagree".

\subsection{Analysis}

SPSS program was used for statistical processes in this study. In the analysis of the data, Skewness and Kurtosis values were examined in order to test whether or not the obtained scores from variables show the normal distribution and it was determined that the data show normal distribution since the values were between +-1.5 (Tabachnick \& Fidell, 2013). In the analysis of data, independent T-test was used in order to determine the difference between two groups, One-Way Variance Analysis-ANOVA was used in order to determine the difference between more than two groups and Scheffe Test was used in order to determine the source of difference between the groups (Büyüköztürk, 2018). The obtained findings were interpreted in a $95 \%$ confidence interval and .05 significance level. The Cronbach's alpha value of the scale calculated for this study was determined as .84 .

\section{Results}

The results of the research are given in the tables below. 
Table 1. T-test results of the sub-dimensions of FSQ according to gender

\begin{tabular}{llllllll}
\hline Sub-Scales & Gender & $\mathbf{n}$ & $\overline{\mathbf{X}}$ & $\mathbf{s d}$ & $\mathbf{t}$ & $\mathbf{d f}$ & $\mathbf{p}$ \\
\hline Information & Female & 604 & 6.02 & .71 & .67 & 1272 & .97 \\
& Male & 670 & 6.03 & .69 & & & \\
Program & Female & 604 & 6.39 & .26 & .47 & 1272 & $.04^{*}$ \\
& Male & 670 & 6.44 & .29 & & & \\
Facility & Female & 604 & 6.39 & .26 & .70 & 1272 & .41 \\
& Male & 670 & 6.44 & .29 & & & \\
\multirow{5}{*}{ Satisfaction } & Female & 604 & 6.27 & .49 & -6.52 & 1272 & $.00^{*}$ \\
& Male & 670 & 6.45 & .45 & & & \\
Loyalty & Female & 604 & 6.21 & .63 & -3.71 & 1272 & $.00^{*}$ \\
& Male & 670 & 6.33 & .60 & & & \\
& Female & 604 & 6.52 & .21 & -6.52 & 1272 & $.00^{*}$ \\
& Male & 670 & 6.59 & .22 & & & \\
\hline
\end{tabular}

Note. $\mathrm{p}<.05$.

Comparison of the sport event satisfaction level of participants in terms of their gender, it was found statistically difference on sub-scales; Program [t(.67)=.1272, $\mathrm{p}<.05]$, Value [t(-6.52)=.1272, $\mathrm{p}<.05]$, Satisfaction $[\mathrm{t}(-3.71)=.1272, \mathrm{p}<.05]$, Loyalty $[\mathrm{t}(-6.52)=.1272, \mathrm{p}<.05]$. After the determination of the mean points, it is found that male participants' mean points higher than females'.

Table 2. ANOVA results of the sub-dimensions of FSQ according to occupational groups

\begin{tabular}{|c|c|c|c|c|c|c|c|c|c|c|}
\hline Sub-scales & $\begin{array}{l}\text { Occupational } \\
\text { Groups }\end{array}$ & $\mathbf{n}$ & $\overline{\mathrm{X}}$ & sd & & $\begin{array}{l}\text { Sum of } \\
\text { Sq. }\end{array}$ & df & $\begin{array}{l}\text { Mean } \\
\text { Sq. }\end{array}$ & $\mathbf{F}$ & $\mathbf{p}$ \\
\hline \multirow[t]{5}{*}{ Information } & Student & 567 & 6.00 & .63 & Bet. G & 8.20 & 3 & 2.73 & & \\
\hline & Private Sector & 228 & 5.93 & .67 & Within G. & 580.79 & 1270 & .45 & & \\
\hline & State & 356 & 6.14 & .67 & Total & 588.99 & 1273 & & 5.97 & $.000^{*}$ \\
\hline & Others & 126 & 6.02 & .80 & & & & & & \\
\hline & Total & 1274 & 6.16 & .68 & & & & & & \\
\hline \multirow[t]{5}{*}{ Program } & Student & 567 & 6.42 & .27 & Bet. G & .32 & 3 & .10 & & \\
\hline & Private Sector & 228 & 6.43 & .26 & Within G. & 96.55 & 1270 & .07 & & \\
\hline & State & 356 & 6.41 & .25 & Total & 96.87 & 1273 & & 1.428 & .23 \\
\hline & Others & 126 & 6.37 & .32 & & & & & & \\
\hline & Total & 1274 & 6.42 & .27 & & & & & & \\
\hline \multirow[t]{6}{*}{ Facility } & Student & 567 & 6.32 & .41 & Bet. G & 14.23 & 4 & 3.55 & & \\
\hline & Private Sector & 228 & 6.24 & .49 & Within G. & 262.52 & 1269 & .207 & & \\
\hline & State & 356 & 6.19 & .52 & Total & 276.75 & 1273 & & 17.19 & $.000^{*}$ \\
\hline & Others & 126 & 6.25 & .38 & & & & & & \\
\hline & Total & 1274 & 6.36 & .48 & & & & & & \\
\hline & Student & 567 & 6.30 & .53 & Bet. G & 13.542 & 4 & 3.38 & & \\
\hline \multirow[t]{4}{*}{ Value } & Private Sector & 228 & 6.23 & .50 & Within G. & 285.070 & 1269 & .225 & & \\
\hline & State & 356 & 6.50 & .35 & Total & 298.612 & 1273 & & 15.071 & $.000^{*}$ \\
\hline & Others & 126 & 6.46 & .34 & & & & & & \\
\hline & Total & 1274 & 6.36 & .48 & & & & & & \\
\hline \multirow[t]{6}{*}{ Satisfaction } & Student & 567 & 6.25 & .66 & Bet. G & 6.633 & 4 & 1.65 & & \\
\hline & Private Sector & 228 & 6.18 & .73 & Within G. & 484.87 & 1269 & .382 & & \\
\hline & State & 356 & 6.32 & .50 & Total & 491.50 & 1273 & & 4.340 & $.002 *$ \\
\hline & Others & 126 & 6.23 & .34 & & & & & & \\
\hline & Total & 1274 & 6.27 & .62 & & & & & & \\
\hline & Student & 567 & 6.54 & .19 & Bet. G & 1.056 & 4 & .264 & & \\
\hline \multirow[t]{4}{*}{ Loyalty } & Private Sector & 228 & 6.50 & .29 & Within G. & 62.069 & 1269 & .049 & & \\
\hline & State & 356 & 6.52 & .21 & Total & 63.125 & 1273 & & 5.395 & $.000^{*}$ \\
\hline & Others & 126 & 6.54 & .19 & & & & & & \\
\hline & Total & 1274 & 6.54 & .22 & & & & & & \\
\hline
\end{tabular}

Note. $\mathrm{p}<.05$.

According to Table 2, it is found that there was statistically difference between all sub-scales except single subscales of event satisfaction scales in terms of occupation. Post-Hoc test applied on data to find the source of 
differences, it may say that state workers event satisfaction points higher than others'.

Table 3. ANOVA results of the sub-dimensions of FSQ according to education level

\begin{tabular}{|c|c|c|c|c|c|c|c|c|c|c|}
\hline Sub-scales & Education Level & $\mathbf{n}$ & $\mathrm{X}$ & sd & & Sum of Sq. & df & Mean Sq. & $\mathbf{F}$ & $\mathbf{p}$ \\
\hline \multirow[t]{4}{*}{ Information } & Primary & 129 & 6.32 & .57 & Bet. G & 13.18 & 2 & 6.59 & 14.54 & \\
\hline & Secondary & 638 & 6.01 & .71 & Within G. & 575.81 & 1271 & .45 & & $.00^{*}$ \\
\hline & Graduate & 507 & 5.97 & .64 & Total & 588.99 & 1273 & & & \\
\hline & Total & 1274 & 6.02 & .68 & & & & & & \\
\hline \multirow[t]{4}{*}{ Program } & Primary & 129 & 6.26 & .27 & Bet. G & .32 & 3 & .10 & 1.428 & .23 \\
\hline & Secondary & 638 & 6.46 & .24 & Within G. & 96.55 & 1270 & .07 & & \\
\hline & Graduate & 507 & 6.40 & .29 & Total & 96.87 & 1273 & & & \\
\hline & Total & 1274 & 6.42 & .27 & & & & & & \\
\hline \multirow[t]{4}{*}{ Facility } & Primary & 129 & 6.36 & .49 & Bet. G & 14.23 & 4 & 3.55 & & \\
\hline & Secondary & 638 & 6.32 & .44 & Within G. & 262.52 & 1269 & .207 & & $.000 *$ \\
\hline & Graduate & 507 & 6.22 & .47 & Total & 276.75 & 1273 & & 17.19 & \\
\hline & Total & 1274 & 6.28 & .46 & & & & & & \\
\hline \multirow[t]{4}{*}{ Value } & Primary & 129 & 6.36 & .49 & Bet. G & 13.542 & 4 & 3.386 & & \\
\hline & Secondary & 638 & 6.32 & .44 & Within G. & 285.070 & 1269 & .225 & & $.000^{*}$ \\
\hline & Graduate & 507 & 6.22 & .47 & Total & 298.612 & 1273 & & 15.071 & \\
\hline & Total & 1274 & 6.28 & .46 & & & & & & \\
\hline \multirow[t]{4}{*}{ Satisfaction } & Primary & 129 & 6.36 & .49 & Bet. G & 6.633 & 4 & 1.658 & & \\
\hline & Secondary & 638 & 6.32 & .44 & Within G. & 484.87 & 1269 & .382 & & $.002 *$ \\
\hline & Graduate & 507 & 6.22 & .47 & Total & 491.50 & 1273 & & 4.340 & \\
\hline & Total & 1274 & 6.28 & .46 & & & & & & \\
\hline \multirow[t]{4}{*}{ Loyalty } & Primary & 129 & 6.36 & .49 & Bet. G & 1.056 & 4 & .264 & & \\
\hline & Secondary & 638 & 6.32 & .44 & Within G. & 62.069 & 1269 & .049 & & $.000 *$ \\
\hline & Graduate & 507 & 6.22 & .47 & Total & 63.125 & 1273 & & 5.395 & \\
\hline & Total & 1274 & 6.28 & .46 & & & & & & \\
\hline
\end{tabular}

Note. $\mathrm{p}<.05$.

In Table 3, the event satisfaction was compared according to educational status. It was found that except program sub-scales, there are significant differences were found all sub-scales of the event satisfaction. When the post-hoc tests are examined, it can be said that the difference is caused by primary school graduates.

\section{Discussion, Conclusion and Suggestions}

In the first problem of the study, the satisfaction levels of participation to the sports events in accordance with the gender were examined and significant differences were determined in program, value, satisfaction and loyalty sub-dimensions. It was observed that the average scores of males were higher than females. According to this result, it can be observed that males were more satisfied from the content of sports events, perceived these events more valuable, would probably participate to this event if it would be organized again and their satisfaction level in these events was significantly higher than females. In accordance with the findings, it is considered that males were more satisfied with the events since the organized sports event was physical and did not include any sports branch that women participate in or females were not interested in these events. In a study conducted by Gürer et al. (2014) on job satisfaction, it was determined that there was a significant relationship between the gender variable and the physical activity that teachers perform variable. In the study of Kelley and Turley (2001) on "Perceptions of consumers towards service quality in sports events", the difference between the gender and service quality perceptions were examined and it was determined that females gave more importance to price-related subjects of service perception in sports events. Furthermore, although it is a different field, in the studies conducted on job satisfaction, it was stated that there wasn't a difference in the job satisfaction of female and male employees in equal conditions. Additionally, in this study that was conducted in addition to a study in which it was stated that obstacles in career have a significant effect on job satisfaction (Akşit \& Aşık, 2010), it was considered that it would be beneficial to motivate women in performing sports and to watch festival, carnival, and competitions as participants and thus, their satisfaction levels in participating sports events would increase.

In the second problem of the study, the satisfaction of participants was compared in accordance with their education level and it was observed that primary school graduates had significantly more satisfaction than 
individuals with different education levels. It was considered that most of the individuals with lower education level had lower income and thus, lower possibility of participating in these events and their satisfaction level was higher since they rarely participate in these events. There weren't any studies to compare in the literature.

In another problem of the study, the satisfaction of participants was compared in accordance with their occupation and it was observed that public employees had less satisfaction than students and employees in private sector and other sectors. Excessive amount of leisure time negatively affects leisure time satisfaction since the essence of leisure time is organizing it and involving voluntary participation (Gökçe \& Orhan, 2011). According to leisure time literature, the satisfaction from leisure time activities is defined as an emotional reaction to the daily activities and the expectancy confirmation level of individuals as well as their physical and social conditions (Schemerhorn et al., 1994).

According to these results;

- the authors suggest that, sport events should be organized according to the characteristics of a target groups.

- Education levels, occupation, expectations etc. are important for society satisfaction level.

- For large event organization, events should have many features within.

\section{Acknowledgement}

This study was presented as oral presentation at $2^{\text {nd }}$ Recreation and Sport Management Congress, Bodrum/Mugla, TURKEY, 11-14 April, 2019.

\section{References}

Anderson, C. A., Gentile, D. A., \& Buckley, K. E. (2007). Violent video game effects on children and adolescents: Theory, research and public policy. https://doi.org/10.1093/acprof:oso/9780195309836.001.0001

Anderson, M. A., Dragsted, S., Evans, R. H., \& Sørensen, H. (2004). The relationship between changes in teachers' self efficacy beliefs and the science teaching environment of Danish first-year elementary teachers. Journal of Science Teacher Education, 15(1), 25-38. https://doi.org/10.1023/B:JSTE.0000031461.68912.3d

Argan, M. T. (2007). Eğlence Pazarlaması. Ankara: Detay Yayıncılık.

Argan, M., Argan, M. T., Köse, H., \& Gökalp, B. (2013). Using Facebook as a sport marketing tool: A content analysis on Turkish soccer clubs. Internet Uygulamaları ve Yönetimi Dergisi, 4(1), 25-35. https://doi.org/10.5505/iuyd.2013.74046

Beck, C. A. J., \& Sales, B. D. (2001). Family mediation: Facts, myths, and future prospects (pp. 100-102). Washington, DC: American Psychological Association. https://doi.org/10.1037/10401-000

Bernstein, T. M. (1965). The careful writer: A modern guide to English usage (2nd ed.). New York, NY: Atheneum.

Bjork, R. A. (1989). Retrieval inhibition as an adaptive mechanism in human memory. In H. L. Roediger III \& F. I. M. Craik (Eds.), Varieties of memory \& consciousness (pp. 309-330). Hillsdale, NJ: Erlbaum.

Büyüköztürk, Ş. (2018). Sosyal bilimler için veri analizi el kitabi (24. Baskı). Ankara: Pegem Akademi. https://doi.org/10.14527/9789756802748

Cole, S. T., \& Illum, S. F. (2006). Examining the mediating role of festival visitors' satisfaction in the relationship between service quality and behavioral intentions. Journal of Vacation Marketing, 12(2), 160 173. https://doi.org/10.1177/1356766706062156

Cress, C. M. (2009). Curricular strategies for student success and engaged learning [PowerPoint slides]. Retrieved

from http://www.vtcampuscompact.org/2009/TCL_post/presenter_powerpoints/Christine\%20Cress\%20-\%20Curr icular\%20Strategies.ppt

Demirci, N. (1986). Spor yönetimi ve organizasyonu. İstanbul: Milli Eğitim Basım Evi.

Doğrul, Ü., Atçeken, K., \& Şahin, A. (2015). The effect of festival quality on visitors perceived value, satisfaction, and loyalty: The case of International Mersin Citrus Festival. Çă̆ Üniversitesi Sosyal Bilimler Dergisi, 1, 72-84.

Driedger, S. D. (1998, April 20). After divorce. Maclean's, 111(16), 38-43.

Eckerstein, A. (2003). Evaluation of event marketing. Rapport nr.: Masters Thesis, 2002. 
Gibbs, J. T., \& Huang, L. N. (Eds.). (1991). Children of color: Psychological interventions with minority youth. San Francisco, CA: Jossey-Bass.

Gilbert, D. G., McClernon, J. F., Rabinovich, N. E., Sugai, C., Plath, L. C., Asgaard, G., ... Botros, N. (2004). Effects of quitting smoking on EEG activation and attention last for more than 31 days and are more severe with stress, dependence, DRD2 A 1 allele, and depressive traits. Nicotine and Tobacco Research, 6, 249267. https://doi.org/10.1080/14622200410001676305

Goldblatt, J. J. (1997). Special events: Best practices in modern event management (2nd ed.). New York: Wiley, Van Nostrand Reinhold.

Goleman, D. (2009). What makes a leader? In D. Demers (Ed.), AHSC 230: Interpersonal communication and relationships (pp. 47-56). Montreal, Canada: Concordia University Bookstore. (Reprinted from Harvard Business Review, 76(6), 93-102, 1998).

Guignon, C. B. (1998). Existentialism. In E. Craig (Ed.), Routledge encyclopedia of philosophy (Vol. 3, pp. 493502). London, England: Routledge.

Healey, D. (2005). Attention deficit/hyperactivity disorder and creativity: An investigation into their relationship. Unpublished doctoral dissertation. University of Canterbury, Christchurch, New Zealand.

Herculano-Houzel, S., Collins, C. E., Wong, P., Kaas, J. H., \& Lent, R. (2008). The basic nonuniformity of the cerebral cortex. Proceedings of the National Academy of Sciences, 105, 12593-12598. https://doi.org/10.1073/pnas.0805417105

Huang, J. Z., Li, M., \& Cai, L. A. (2010). A model of community-based festival image. International Journal of Hospitality Management, 29(2), 254-260. https://doi.org/10.1016/j.ijhm.2009.10.010

Johnston, J., \& Zawawi, C. (2004). Public relations: Theory and practice (2nd ed.). Allen \& Unwin.

Kelley, S. W., \& Turley, L. W. (2001). Consumer perceptions of service quality attributes at sporting events. Journal of Business Research, 54(2), 161-166. https://doi.org/10.1016/S0148-2963(99)00084-3

Klimoski, R., \& Palmer, S. (1993). The ADA and the hiring process in organizations. Consulting Psychology Journal: Practice and Research, 45(2), 10-36. https://doi.org/10.1037/1061-4087.45.2.10

Kubrick, S. (Director). (1980). The Shining [Motion picture]. United States: Warner Brothers.

Lee, S. Y., Petrick, J. F., \& Crompton, J. (2007). The roles of quality and intermediary constructs in determining festival attendees' behavioral intention. Journal of Travel Research, 45(4), 402-412. https://doi.org/10.1177/0047287507299566

Liu, S. (2005, May). Defending against business crises with the help of intelligent agent based early warning solutions. Paper presented at the Seventh International Conference on Enterprise Information Systems, Miami, FL. Abstract retrieved from http://www.iceis.org/iceis2005/abstracts_2005.htm

MacIntyre, L. (Reporter). (2002, January 23). Scandal of the Century [Television series episode]. In H. Cashore (Producer), The fifth estate. Toronto, Canada: Canadian Broadcasting Corporation.

McDonnell, I., Allen, J., \& O’Toole, W. (1999). Festival and special event management. John Wiley \& Sons, Chichester.

McLuhan, M. (1970a). Culture is our business. New York, NY: McGraw-Hill.

McLuhan, M. (1970b). From cliche to archetype. New York, NY: Viking Press.

Mellers, B. A. (2000). Choice and the relative pleasure of consequences. Psychological Bulletin, 126, 910-924. https://doi.org/10.1037/0033-2909.126.6.910.

Oliver, R. L. (1980). A cognitive model for the antecedents and consequences of satisfaction. Journal of Marketing Research, 17, 460-469. https://doi.org/10.2307/3150499.

Parasuraman, A., Zeithaml, V. A., \& Berry, L. L. (1985). A conceptual model of service quality and its implications for future research. Journal of Marketing, 49(4), 41-50. https://doi.org/10.1177/002224298504900403

Postman, N. (1979). Teaching as a conserving activity. New York, NY: Delacorte Press.

Postman, N. (1985). Amusing ourselves to death: Public discourse in the age of show business. New York, NY: Viking.

Rızaoğlu, B. (2003). Turizm davranışı (2. Basım). Ankara: Detay Yayıncılık. 
Schermerhorn, J. R, Hunt, J. G., \& Osborn, R. N. (1994). Management. New York: John Wiley and Sons.

Semenak, S. (1995, December 28). Feeling right at home: Government residence eschews traditional rules. Montreal Gazette, A4.

Shone, A., \& Parry, B. (2004). Successful event management: A practical handbook. Cengage Learning EMEA.

Silver, E., Costa Pisani, P., Hutnak, M., Fisher, A., DeShon, H., \& Taylor, B. (2004). An 8-10 Ma tectonic event on the Cocos Plate offshore Costa Rica: Result of Cocos Ridge collision? Geophysical Research Letters, 31(18), 1-4. https://doi.org/10.1029/2004GL020272

Strong, E. K. Jr., \& Uhrbrock, R. S. (1923). Bibliography on job analysis. In L. Outhwaite (Series Ed.), Personnel Research Series (Vol. 1. Job analysis and the curriculum, pp. 140-146). https://doi.org/10.1037/10762-000.

Tabachnick, B. G., \& Fidell, L. S. (2013). Using Multivariate Statistics (6th ed.). Boston, MA: Pearson.

Tassiopoulos, D. (2005) Events-an introduction. In D. Tassiopoulos (Ed.), Event Management: A professional and developmental approach (2nd ed., pp. 2-36). Juta Academic, South Africa.

Theodorakis, N. D., \& Alexandris, K. (2008). Can service quality predict spectators' behavioral intentions in professional soccer? Managing Leisure, 13(3-4), 162-178. https://doi.org/10.1080/13606710802200852

Theodorakis, N. D., Alexandris, K., Tsigilis, N., \& Karvounis, S. (2013). Predicting spectators' behavioural intentions in professional football: The role of satisfaction and service quality. Sport Management Review, 16(1), 85-96. https://doi.org/10.1016/j.smr.2012.05.004

Thrane, C. (2002). Jazz festival visitors and their expenditures: linking spending patterns to music interest. Journal of Travel Research, 40(3), 281-286. https://doi.org/10.1177/0047287502040003006

Vu, T. H., \& Wang, J. C. (2016). Acoustic scene and event recognition using recurrent neural networks. Detection and Classification of Acoustic Scenes and Events, 2016.

Yoon, Y. S., Lee, J. S., \& Lee, C. K. (2010). Measuring festival quality and value affecting visitors' satisfaction and loyalty using a structural approach. International Journal of Hospitality Management, 29(2), 335-342. https://doi.org/10.1016/j.ijhm.2009.10.002

Zeithaml, V. A., Berry, L. L., \& Parasuraman, A. (1996). The behavioral consequences of service quality. The Journal of Marketing, 60(2), 31-46. https://doi.org/10.2307/1251929

\section{Copyrights}

Copyright for this article is retained by the author, with first publication rights granted to the journal.

This is an open-access article distributed under the terms and conditions of the Creative Commons Attribution license (http://creativecommons.org/licenses/by/4.0/). 